\title{
Effects of castration and testosterone replacement on peritoneal histamine concentration and lung histamine concentration in pubertal male rats
}

\author{
A P Lima, L O Lunardi ${ }^{1}$ and A A M Rosa e Silva \\ Department of Physiology, Faculty of Medicine of Ribeirão Preto, University of São Paulo, Ribeirão Preto, São Paulo, Brazil \\ ${ }^{1}$ Department of Morphology, Faculty of Odontology of Ribeirão Preto, University of São Paulo, Ribeirão Preto, São Paulo, Brazil \\ (Requests for offprints should be addressed to A A M Rosa e Silva)
}

\begin{abstract}
Mast cells, which are the main source of histamine, are significantly affected by sex steroids. The present study was undertaken to determine the effects of bilateral castration and testosterone replacement on peritoneal histamine concentration and lung histamine concentration in pubertal male rats (Wistar strain). Three groups of animals were used in this study: (1) untreated castrated animals, (2) castrated animals subjected to androgen replacement by injection of propionate of testosterone, and (3) intact males as a control group. Castration alone produced a dramatic reduction in peritoneal histamine concentration. In addition, androgen replacement was effective in restoring the histamine concentration to the normal value
\end{abstract}

detected in the control males $(P<0 \cdot 05$, Kruskal-Wallis test). On the other hand, there was no significant variation in the lung histamine concentration between control males, untreated castrated males and castrated males that received androgen replacement $(P<0 \cdot 05$, Kruskal-Wallis test). These results demonstrate for the first time that castration markedly reduces the peritoneum histamine concentration in pubertal male rats, and testosterone replacement prevents the decrease. Further, these procedures do not affect lung histamine concentration, demonstrating that mast cells from different tissues may respond differently to the same biological factors.

Journal of Endocrinology (2000) 167, 71-75

\section{Introduction}

Mast cells have been studied mainly for their involvement in allergic and inflammatory reactions where they secrete biological mediators in response to immunoglobulin $\mathrm{E}$ (IgE) and specific antigens (Ags) (Serafin \& Austen 1987). Historically, the classification of rodent mast cell subtypes has been based on phenotypical differences between connective tissue mast cells (CTMC), of which peritoneal mast cells are the most studied example, and mucosal mast cells $(\mathrm{MMC})$, particularly of the intestinal lamina propria and lung (Enerback 1986, Galli 1986, Kitamura et al. 1986).

A growing body of evidence suggests that mast cells are regulated by the neuroimmunendocrine system. Many authors have reported that mast cells are significantly affected by sex steroids. In general, it seems that estrogens and androgens exert opposite effects on mast cells in rodents: while estrogens appear to stimulate cell proliferation (Modat et al. 1982, Gaytan et al. 1989, 1990, Jaiswal \& Krishna 1996), most studies indicate that testosterone is an inhibitory factor of cell proliferation (Payne et al. 1982, Shirama et al. 1988, Menendez-Pelaez et al. 1992). More- over, sex-associated differences in the number of mast cells have been described in a variety of tissues from rodents, the females having a larger number of mast cells than the males (Payne et al. 1982, Shirama et al. 1988, MenendezPelaez et al. 1992). However, the role of androgens and ovarian steroids in the regulation of mast cells is still unclear.

Since mast cells are the main source of histamine, the present study was conducted to determine the effects of castration and testosterone replacement on (1) peritoneal histamine concentration and (2) lung histamine concentration in pubertal male rats.

\section{Materials and Methods}

\section{Animals}

Male rats of the Wistar strain were used in this study. All animals were housed in plastic boxes $(40 \mathrm{~cm} \times$ $32 \mathrm{~cm} \times 17 \mathrm{~cm}$ ), six animals per cage, in a light- and temperature-controlled room (12 h light: $12 \mathrm{~h}$ darkness; $22 \pm 2{ }^{\circ} \mathrm{C}$ ) with food and water available ad libitum. At the 
end of the study all animals were killed by decapitation between $0900 \mathrm{~h}$ and $1000 \mathrm{~h}$.

\section{Experimental procedures}

In order to study the effect of testosterone on histamine concentration, the following experiments were designed. Male rats (21 days old) were bilaterally castrated under tribromo-ethanol anaesthesia and divided into five groups of six animals each: untreated castrated animals (1), and animals subjected to replacement treatment by injection of propionate of testosterone at concentrations of 50 (2), 100 (3), 200 (4) and $300 \mu \mathrm{g} / 100 \mathrm{~g}$ body weight (5). The untreated castrated animals received dilution vehicle (oil). These groups received a daily subcutaneous injection from the 24th to the 40th day of age. All animals were weighed and killed at 41 days of age. Intact males (41 days old) were used as a control group.

\section{Measurement of plasma testosterone concentration}

After decapitation, blood was collected and plasma was separated by centrifugation and stored at $-20{ }^{\circ} \mathrm{C}$ for the determination of testosterone concentration. Testosterone was measured by the radioimmunoassay method described by Bélanger et al. (1980), slightly modified by our group.

\section{Measurement of lung histamine concentration}

The right lung was removed and immersed in a cold solution of $0.4 \mathrm{~N}$ perchloric acid for histamine determination. The homogenate was centrifuged at $1900 \mathrm{~g}$ at $4{ }^{\circ} \mathrm{C}$ for $10 \mathrm{~min}$. The organic portion was removed and discarded. The supernatant was collected and stored at $-20{ }^{\circ} \mathrm{C}$ for the determination of histamine concentration.

\section{Measurement of peritoneal histamine concentration}

After decapitation, $10 \mathrm{ml}$ saline solution was injected into the peritoneum and the abdomen was massaged for $1 \mathrm{~min}$. The peritoneal cavity was opened and the fluid collected with a Pasteur pipette. The peritoneal fluid was added to $3 \mathrm{ml} 0.4 \mathrm{~N}$ perchloric acid. The homogenate was centrifuged for $10 \mathrm{~min}$ at $1900 \mathrm{~g}$ at $4{ }^{\circ} \mathrm{C}$. For histamine measurement, the supernatant was collected and stored at $-20{ }^{\circ} \mathrm{C}$. The organic part was discarded.

\section{Histamine extraction and assay}

Quantification of histamine was achieved by the method described by Shore et al. (1959). The intensity of fluorescence provides a base for the calculation of histamine percentage.

\section{Statistical analysis}

Statistical analysis was carried out using analysis of variance and Kruskal-Wallis's multiple-comparison methods. $P$ values $<0 \cdot 05$ were considered significant.

\section{Results}

\section{Plasma testosterone concentration}

As shown in Fig. 1, castration alone produced a significant decrease in plasma testosterone concentration. The castrated animals subjected to androgen replacement presented a markedly higher plasma testosterone concentration compared with that observed in untreated castrated animals. All the concentrations used for the androgen replacement therapy were sufficient to raise testosterone concentration to supraphysiological levels.

\section{Peritoneal histamine concentration}

Figure 2 shows the peritoneal histamine concentration in intact and castrated pubertal male rats. Castration alone produced a dramatic redution in the histamine concentration. Androgen replacement prevented the decrease in histamine concentration since all the castrated animals subjected to androgen replacement presented a higher histamine concentration compared with that observed in untreated castrated animals. However, only the propionate testosterone concentration of $50 \mu \mathrm{g} / 100 \mathrm{~g}$ body weight was effective in restoring histamine concentration to the normal value detected in control males. The other concentrations (100, 200 and $300 \mu \mathrm{g} / 100 \mathrm{~g}$ body weight), although they raised histamine concentration in comparison to untreated castrated males, were unable to restore histamine concentration to the control level.

\section{Lung histamine concentration}

As shown in Fig. 3, castration alone and castration with androgen replacement did not affect the lung histamine concentration, since there was no significant variation in the histamine concentration between control males, untreated castrated males and castrated males that received androgen replacement.

\section{Discussion}

Peritoneal and lung histamine concentrations were analysed in intact male rats and castrated male rats with or without androgen replacement. The present results show that castration alone produced a dramatic reduction in peritoneal histamine concentration. The castrated animals subjected to androgen replacement presented a higher histamine concentration than untreated castrated animals. 

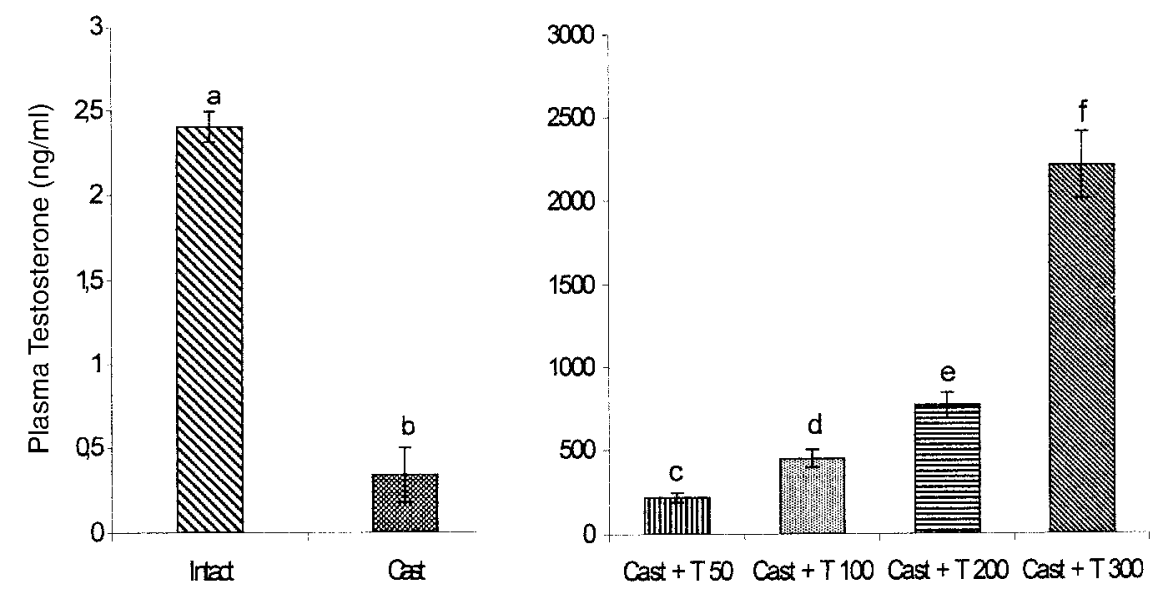

Figure 1 Effect of castration and of testosterone replacement on plasma testosterone concentration of pubertal male rats. Twenty-one-day-old male rats were castrated and received the dilution vehicle (Cast) or testosterone propionate at 50 (Cast $+\mathrm{T} 50), 100$ (Cast $+\mathrm{T} 100)$, 200 (Cast $+\mathrm{T}$ 200) and $300 \mu \mathrm{g} / 100 \mathrm{~g}$ body weight (Cast+T 300). Replacement treatment consisted of daily subcutaneous injection from 24 to 40 days of age. The control group (Intact) consisted of uncastrated males. Animals in all groups were killed at 41 days old. Data were obtained by radioimmunoassay and are reported as means \pm S.E.M. for six rats in each group. Different letters indicate statistically significant differences between means: $a \neq b \neq c \neq d \neq$ $e \neq f(P<0 \cdot 05$, Kruskal-Wallis test $)$.

All administered concentrations of testosterone propionate increased histamine concentration in comparison with untreated castrated animals, but only the concentration of $50 \mu \mathrm{g} / 100 \mathrm{~g}$ body weight was effective in restoring histamine concentration to the normal value detected in control males. The higher concentrations $(100,200$ and

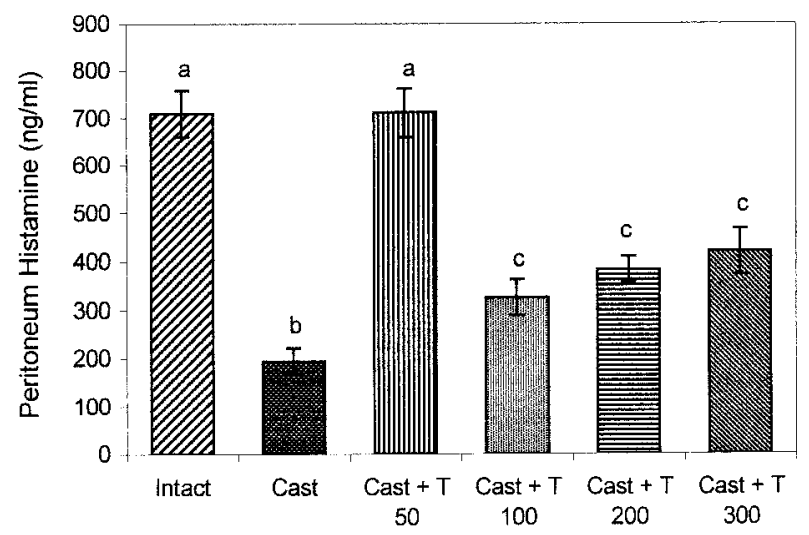

Figure 2 Effect of castration and of testosterone replacement on peritoneal histamine concentration in pubertal male rats. Twenty-one-day-old male rats were castrated and received the dilution vehicle (Cast) or testosterone propionate at 50 (Cast+T 50), 100 (Cast $+\mathrm{T} 100), 200$ (Cast $+\mathrm{T} 200)$ and $300 \mu \mathrm{g} / 100 \mathrm{~g}$ body weight (Cast $+\mathrm{T}$ 300). Replacement treatment consisted of daily subcutaneous injection from 24 to 40 days old. The control group (Intact) consisted of uncastrated males. All groups were killed at 41 days old. Data were obtained by radioimmunoassay and are reported as means \pm S.E.M. for six rats in each group. Different letters indicate statistically significant differences between the means: $a \neq b \neq c(P<0 \cdot 05$, Kruskal-Wallis test $)$.
$300 \mu \mathrm{g} / 100 \mathrm{~g}$ body weight) were unable to restore the peritoneal histamine concentration to control levels. The concentration of $50 \mu \mathrm{g} / 100 \mathrm{~g}$ body weight was probably effective because it is so low. It is possible that mast cells are stimulated by testosterone at lower concentrations but inhibited by testosterone at higher concentrations.

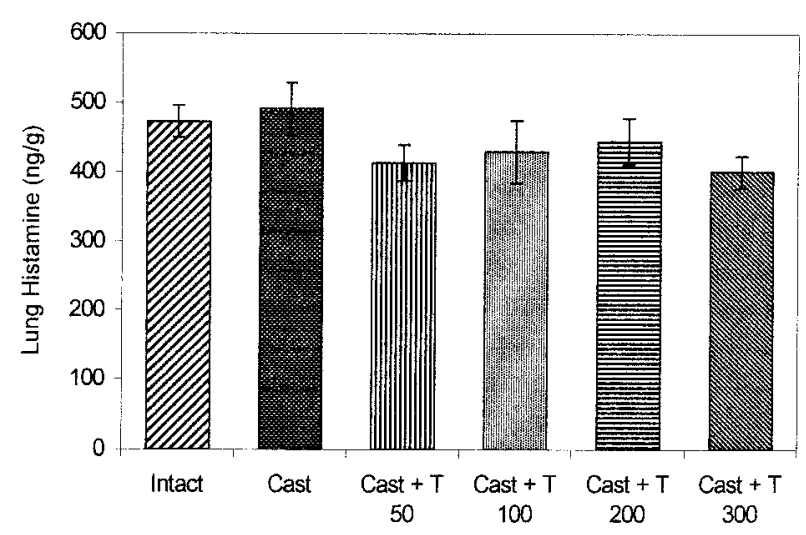

Figure 3 Effect of castration and of testosterone replacement on lung histamine concentration of pubertal male rats. Twenty-oneday-old male rats were castrated and received the dilution vehicle (Cast) or testosterone propionate at 50 (Cast+T 50), 100 (Cast $+\mathrm{T}$ 100), 200 (Cast+T 200) and $300 \mu \mathrm{g} / 100 \mathrm{~g}$ body weight (Cast $+\mathrm{T}$ 300). Replacement treatment consisted of daily subcutaneous injection from 24 to 40 days old. The control group (Intact) consisted of uncastrated males. All groups were killed at 41 days old. Data were obtained by radioimmunoassay and are reported as means \pm S.E.M. for six rats in each group. There was no significant difference between groups $(P<0 \cdot 05$, Kruskal-Wallis test). 
The present experiment was effective in demonstrating the stimulatory role of testosterone on histamine concentration in the peritoneum of pubertal male rats. The main issue to resolve is whether the observed increase in histamine concentration in the castrated males treated with testosterone is due to an increase in number of mast cells or whether testosterone stimulates mast cell maturation, and consequently, their histamine storage capacity. Histamine concentration can be used as an index of mast cell density, since mast cells are the main source of histamine. There is a correlation between mast cell number and histamine content in tissues. For instance, rat peritoneal mast cells contain approximately 10-30 pg histamine/cell, whereas mucosal mast cells have lower amounts $(1-3 \mathrm{pg} /$ cell) (Metcalfe et al. 1997). On this basis, a reduction in histamine concentration in the peritoneum after castration may be associated with a decreased number of mast cells.

Unlike the observed results for peritoneum, castration alone and castration with androgen replacement did not affect lung histamine concentration. This result may be due to the fact that mast cells exhibit a diversity of histological, biochemical and functional properties depending on the species and their anatomical location within the same species (Chiu \& Lagunoff 1972, Barret \& Metcalfe 1984, Befus et al. 1985). Moreover, lung mast cells are classified as mucosal mast cells, while peritoneal mast cells are considered connective tissue mast cells. These subtypes show differences in function, including responsiveness to various secretagogues and inhibition by drugs (Metcalfe et al. 1997). Therefore, it is reasonable that these two populations respond differently to the same biological factors.

To our knowledge, the present study is the first to report on the effects of castration and androgen replacement on lung histamine concentration and peritoneal histamine concentration during puberty in male rats. The hormonal regulation of mast cells has been extensively studied in different species and different tissues within the same species. Sex differences in number of mast cells have been described in a variety of tissues from rodents (Hellstrom \& Holmgren 1950, Payne et al. 1982, Shirama et al. 1988). In general, most reports indicate that females have a larger number of mast cells than males. Previous work on male rodents has shown that castration results in a significant increase in mast cell numbers in the Harderian gland of hamsters and mice, while administration of testosterone prevents the increase (Payne et al. 1982, Shirama et al. 1988). In addition, administration of testosterone to female Syrian hamsters results in a decrease in number of recognizable mast cells in the Harderian gland (Menendez-Pelaez et al. 1992). Thus, testosterone seems to play an important inhibitory role in the Harderian mast cell population as reported by other authors. On the other hand, castration significantly decreases the number of mast cells in the thymus, while testosterone replacement prevents the decrease (Barbini et al. 1981), which indicates that testosterone stimulates mast cells in the thymus. Likewise, our results indicate that testosterone also stimulates mast cells from peritoneum. Taking our results and data in the literature together it seems that mast cells from different tissues and species may respond differently to castration and testosterone replacement.

Finally, in the present investigation we observed that castration alone produces a marked reduction in peritoneal histamine concentration in pubertal male rats, and that androgen replacement prevents the decrease. However, castration alone and castration with androgen replacement did not affect the lung histamine concentration, demonstrating that mast cells from different tissues may respond differently to the same biological factors.

\section{Acknowledgements}

This work was supported by grants from FAPESP. We would like to thank Rogerio Rosario de Azevedo and Kátia Jacqueline Miguel for their technical assistance.

The authors are deeply indebted to Dr José Carlos Gomes, for allowing us to carry out the quantification of histamine concentration at his laboratory.

\section{References}

Barbini A, Gheri Bryk S \& Balboni GC 1981 Behavior of thymus mast cells in the rat under various experimental conditions. Bollettino - Societa Italiana Biologia Sperimentale 57 645-650.

Barret KE \& Metcalfe DD 1984 Mast cell heterogeneity: evidence and implications. Journal of Clinical Immunology 4 253-261.

Befus D, Goodacre R \& Bienenstock J 1985 Mast cell heterogeneity in man: histologic studies of the intestine rat. International Archives of Allergy and Applied Immunology 76 232-236.

Bélanger A, Caron S \& Picard V 1980 Simultaneous radioimmunoassay of progestins, androgens and estrogens in rat testis. Journal of Steroid Biochemistry 13 185-190.

Chiu H \& Lagunoff D 1972 Histochemical comparison of vertebrate mast cells. Histochemical Journal 4 135-144.

Enerback L 1986 Mast cell heterogeneity: the evolution of the concept of specific mucosal mast cell. In Mast Cell Differentiation and Heterogeneity, pp 1-26. Eds AD Befus, J Bienenstock \& JA Denburg. New York: Raven Press.

Galli SJ 1986 Mast cell heterogeneity: can variation in mast cell phenotype be explained without postulating the existence of distinct mast cells lineages? In Cell Differentiation and Heterogeneity, pp 167-181. Eds AD Befus, J Bienenstock \& JA Denburg. New York: Raven Press.

Gaytan F, Carrera G, Pinilla L, Aguilar R \& Bellido C 1989 Mast cells in the testis, epididymis and accessory glands of the rat: effects of neonatal steroid treatment. Journal of Andrology 10 351-358.

Gaytan F, Bellido C, Carrera G \& Aguilar E 1990 Differentiation of mast cells during postnatal development of neonatally estrogen-treated rats. Cell and Tissue Research 259 25-31.

Hellstrom B \& Holmgren HJ 1950 Numerical distribution of mast cells in the human skin and heart. Acta Anatomica 10 81-107. 
Jaiswal K \& Krishna A 1996 Effects of hormones on the number, distribution and degranulation of mast cells in the ovarian complex of mice. Acta Physiologica Hungarica 84 183-190.

Kitamura Y, Nakano T, Sonoda T, Kanayama T, Yamamura T \& Asai H 1986 Probable transdifferentiation between connective tissue and mucosal mast cell. In Cell Differentiation and Heterogeneity, pp 135-140. Eds AD Befus, J Bienenstock \& JA Denburg. New York: Raven Press.

Menendez-Pelaez A, Mayo JC, Sainz RM, Perez M, Antolin I \& Tolivia D 1992 Development and hormonal regulation of mast cells in the harderian gland of syrian hamsters. Anatomy and Embryology 186 91-97.

Metcalfe DD, Baram B \& Mekori YA 1997 Mast cells. Physiological Reviews 77 1033-1079.

Modat G, Benmbareck A \& Lalaurie M 1982 Quantitative variations in the number and size of peritoneal mastocytes in the female rat during the normal sexual cycle, following ovariectomy and administration of estrogens. Comptes Rendus des Seances de la Societe de Biologie et de Filiales 176 675-680.
Payne AP, McGadey J, Johnston HS, Moore MR \& Thompson GG 1982 Mast cells in the hamster harderian gland: sex differences, hormonal control and relationship to porphyrin. Journal of Anatomy 135 451-461.

Serafin WE \& Austen KF 1987 Mediators of immediate hypersensitivity reactions. New England Journal of Medicine 317 $30-34$.

Shirama K, Kohda M \& Kohano M 1988 Effects of endocrine glands and hormone replacement on mast cell count of the harderian gland of mice. Acta Anatomica 131 327-331.

Shore PA, Burkhalter A \& Cohn VH 1959 A method for the flurometric assay of histamine in tissues. Journal of Pharmacology and Experimental Therapeutics 127 182-186.

Received 8 February 2000

Revised manuscript received 2 June 2000 Accepted 8 June 2000 